\title{
Analisis Karakteristik Wanita Usia Subur, Dukungan Suami, dan Peran Bidan terhadap Unmet Need Keluarga Berencana di Wilayah Kerja Puskesmas Bungus Kota Padang
}

\author{
Yollanda Dwi Santi Violentina ${ }^{1}$, Husna Yetti², Arni Amir ${ }^{3}$
}

\begin{abstract}
Abstrak
Salah satu permasalahan Keluarga Berencana (KB) yaitu unmet need. Tingginya unmet need KB dapat disebabkan oleh karakteristik wanita usia subur, dukungan suami, dan peran bidan. Tujuan: Menganalisis hubungan antara karakteristik wanita usia subur, dukungan suami, dan peran bidan terhadap unmet need KB di wilayah kerja Puskesmas Bungus. Metode: Studi analitik dengan desain case-control. Sampel diambil menggunakan sistemic random sampling pada 178 Wanita Usia Subur (WUS) dengan unmet need KB dan 178 WUS yang memakai KB antara Maret sampai Mei 2019. Hasil: Sebagian besar WUS dengan unmet need KB memiliki umur berisiko (49,4\%), berpendidikan menengah (82,6\%), jumlah anak 2-4 orang (82\%), status ekonomi kategori miskin $(33,1 \%)$, tidak mendapat dukungan suami (73\%), dan peran bidan kurang baik $(75,3 \%)$. Terdapat hubungan unmet need KB dengan jumlah anak, dukungan suami dan peran bidan $(p<0,05)$. Faktor yang paling dominan adalah dukungan suami $(\mathrm{OR}=100,504)$. Simpulan: Dukungan suami dan peran bidan adalah faktor yang menyebabkan tingginya unmet need KB di wilayah kerja Puskesmas Bungus Kota Padang.
\end{abstract}

Kata kunci: dukungan suami, peran bidan, unmet need KB

\begin{abstract}
One of the problems of family planning (FP) is the unmet need. High unmet need family planning can be caused by the characteristics of reproductive age women, husband's support and the role of the midwife. Objectives: To analyzed the relationship between the characteristics of women of reproductive age, support the husband, and the role of the midwife's response on unmet needs in the working area of Bungus's Health Center. Methods: This study used analytic method with a case-control design. Samples were taken by systematic random sampling in 178 of women of reproductive age with an unmet need FP and 178 of women of reproductive age with FP in Bungus between March to May 2019. Results: The most of the unmet need for family planning in women of reproductive age has a life span of risk (49.4\%), secondary education (82.6\%), has 2-4 children (82\%), poor economic status (33.1\%), their husband's don't support to use a contraception (73\%), and less of midwives role (75.3\%). There is a relationship with an unmet need family planning with the number of children, the support of husband and the midwives' role ( $p$ $<0.05)$. The most dominant factor is husband support $(O R=100,504)$. Conclusion: The husband's support and role of midwives are factors which made the high unmet need family planning in Bungus Padang
\end{abstract}

Keywords: husband's support, the role of midwife, unmet need for family planning

Affiliasi penulis: 1. Program Studi Magister Kebidanan Fakultas Kedokteran, Universitas Andalas, Padang, Indonesia 2. Bagian IImu Kesehatan Masyarakat, Fakultas Kedokteran, Universitas Andalas, Indonesia. 3. Bagian Biologi, Fakultas Kedokteran, Universitas Andalas, Indonesia.

Korespondensi: dr. Husna Yetti, PhD

Email:ollaviolentina@yahoo.co.id Telp : 081378653451

\section{PENDAHULUAN}

Pertumbuhan penduduk Indonesia mengalami peningkatan sekitar 3,5 juta lebih per tahun sehingga dapat diperkirakan pada tahun 2035 jumlah penduduk akan mencapai 343,96 juta jiwa. Hal ini dapat 
disimpulkan bahwa laju pertumbuhan penduduk di Indonesia rata-rata yaitu $1,49 \%$ per tahun. Tingginya laju pertumbuhan penduduk akan berdampak pada berbagai sektor seperti penyediaan pangan, lahan pertanian, perumahan dan barang konsumsi lainnya. ${ }^{1}$

Laju pertumbuhan penduduk dapat ditekan dengan adanya Program Keluarga Berencana (KB). Program Keluarga Berencana (KB) memiliki tujuan yang jelas yaitu menurunkan kesuburan (fertilitas) agar dapat mengurangi beban pembangunan demi terwujudnya kebahagiaan dan kesejahteraan bagi rakyat dan bangsa Indonesia. Keluarga Berencana (KB) juga merupakan upaya untuk meningkatkan kepedulian dan peran serta masyarakat melalui pendewasaan usia perkawinan, pengaturan kelahiran, pembinaan ketahanan keluarga, dan peningkatan kesejahteran keluarga guna mewujudkan keluarga kecil, bahagia dan sejahtera. ${ }^{2}$

Program Keluarga Berencana (KB) di Indonesia telah diakui secara nasional dan internasional sebagai salah satu program yang telah berhasil menurunkan angka fertilitas. ${ }^{3}$ Hasil Survei Demografi Kesehatan Indonesia (SDKI) tahun 2012, Total Fertility Rate (TFR) sebesar 2,6 menurun menjadi 2,4 pada SDKI 2017.4 Menurunnya capaian Total Fertility Rate bukan berarti permasalahan kependudukan dan keluarga berencana di Indonesia selesai. Terdapat permasalahan antara lain laju pertumbuhan penduduk (LPP) yang terus meningkat, capaian total fertility rate (TFR) yang masih tinggi, capaian contraceptive prevalence rate $(C P R)$ yang belum sesuai target dan cakupan unmet need contraception yang masih tinggi. ${ }^{5}$

Salah satu dari permasalahan keluarga berencana yang menjadi sorotan yaitu unmet need keluarga berencana. Unmet need Keluarga Berencana (KB) adalah wanita usia subur yang membutuhkan KB tetapi tidak terpenuhi. Wanita yang berada dalam usia subur yang tidak menginginkan anak pada dua tahun ke depan (spacers) atau tidak menginginkan anak lagi (limiters) dan tidak menggunakan metode kontrasepsi apapun. $^{3}$

Alasan wanita usia subur memilih untuk tidak memanfaatkan program $\mathrm{KB}$, sebanyak $6,15 \%$ ingin menunda memiliki anak/Ingin Anak Tunda (IAT) dan $6,55 \%$ tidak ingin memiliki anak lagi. ${ }^{6}$ Angka unmet need tahun 2015 mengalami penurunan dibandingkan tahun 2014 yaitu 14,87\% menjadi 12,7\%, tetapi masih belum sesuai dengan target yaitu sekitar $6,5 \%$ dari jumlah pasangan usia subur. ${ }^{7}$

Tingginya unmet need bukan hanya akan menjadi penyebab ledakan penduduk (populasi), melainkan juga bisa berpengaruh pada tingginya Angka Kematian lbu (AKI) di Indonesia, karena merupakan salah satu faktor penyebab $75 \%$ kematian ibu di Indonesia dan juga di dunia. Wanita usia reproduksi yang tidak menggunakan KB berpeluang besar untuk hamil dan mengalami komplikasi dalam masa kehamilan, persalinan dan nifas. Hal ini dapat disebabkan dari adanya aborsi karena kehamilan yang tidak diinginkan (unwanted pregnancy), jarak hamil terlalu dekat, melahirkan terlalu banyak maupun komplikasi penyakit selama kehamilan, penyulit saat persalinan dan komplikasi masa nifas. ${ }^{5}$

Hasil penelitian Nzokirishaka et al di daerah Burundi, Afrika mendapatkan data bahwa pada tahun 2010 hingga tahun 2011 kebutuhan keluarga berencana yang tidak terpenuhi mencapai $29,2 \%$. Hal ini disebabkan oleh berbagai faktor, diantaranya usia, pendidikan terakhir, status ekonomi, jumlah anak, dukungan suami, dan akses pelayanan kesehatan. ${ }^{8}$ Penelitian lain oleh Lutalo et al di negara Uganda didapatkan hasil bahwa kebutuhan keluarga berencana yang tidak terpenuhi mencapai angka $28 \%$. Hal ini disebabkan oleh usia, jumlah anak, status perkawinan, letak tempat tinggal, pendidikan terakhir, dan status ekonomi. ${ }^{9}$

Penelitian di Dangila Ethiopia oleh Genet et al, mendapatkan bahwa peran dari petugas kesehatan seperti perawat dan bidan dalam memberikan informasi kesehatan dan keluarga berencana melalui konseling berpengaruh terhadap pengambilan keputusan wanita usia subur dan pasangan usia subur untuk tidak memilih unmet need keluarga berencana. ${ }^{10}$ Penelitian Ernani pada tahun 2012 di Kalimantan Timur menunjukkan bahwa tingginya angka unmet need disebabkan oleh kurangnya peran bidan dalam pemberian Komunikasi, Informasi, dan Edukasi (KIE). Bidan sebagai salah satu tenaga kesehatan memiliki peran yang penting dalam membantu menyukseskan program keluarga berencana. Pendekatan yang dapat dilakukan Bidan adalah dengan memberikan Komunikasi, Informasi, dan Edukasi (KIE). ${ }^{11}$ Hasil 
penelitian dari Umariyah et al di Semarang juga mendapatkan hasil bahwa peran bidan terkait dengan kegiatan Komunikasi, Informasi, dan Edukasi Keluarga Berencana (KB) oleh bidan yaitu memberikan penyuluhan dan konseling kesehatan reproduksi perempuan dan keluarga berencana terbukti berpengaruh terhadap kebutuhan keluarga berencana yang tidak terpenuhi (unmet need). ${ }^{12}$

Salah satu daerah di Indonesia yang masih memiliki angka unmeet need yang tinggi adalah Sumatera Barat. Sumatera Barat menduduki urutan ke-18 tertinggi. ${ }^{13}$ Pada akhir tahun 2016 kebutuhan ber KB yang tidak terlayani atau unmet need di Sumatera Barat adalah sebesar 18,35 \% dengan target $11,1 \%$ capaian kinerja sebesar $65,3 \%$, angka ini menunjukan belum bisa tercapainya penurunan unmet need sebesar $11,1 \%$. Terjadinya kenaikan persentase kebutuhan ber KB yang tidak terpenuhi pada akhir tahun 2016, disebabkan karena berbagai hal, diantaranya adalah alat kontrasepsi yang tidak tersedia dalam beberapa bulan pada tahun 2016 , seperti IUD, Implant dan suntik. ${ }^{14}$

Kota Padang memiliki jumlah pasangan usia subur 113.586 orang yang tersebar di 11 kecamatan kota Padang. Pasangan usia subur peserta KB aktif berjumlah 70.408 orang, sedangkan PUS yang bukan peserta KB berjumlah 43.178 orang, ingin menunda anak (IAT) 9.804 orang, dan yang tidak ingin anak lagi (TIAL) 13.192 orang. Oleh karena itu kota Padang memiliki angka unmet need sebesar 20,2\%. Kecamatan Bungus Teluk Kabung merupakan kecamatan yang memiliki jumlah unmet need KB tertinggi yaitu $29,7 \%$ dengan jumlah yang ingin menunda anak (IAT) 9.804 orang, dan yang tidak ingin anak lagi (TIAL) sebanyak 13.192 orang, yang tersebar pada 6 kelurahan. ${ }^{15}$

Puskesmas Bungus merupakan puskesmas yang berada di kawasan Kecamatan Bungus Teluk Kabung Kota Padang. Berdasarkan data pada Bulan Agustus 2018 angka unmet need di daerah ini sebesar 29,6\% dengan jumlah PUS di wilayah kerja puskesmas ini sebanyak 4.082 orang, jumlah yang ingin menunda anak (IAT) sebanyak 18,3\%, dan yang tidak ingin anak lagi (TIAL) sebanyak 43,5\%. ${ }^{16}$

Unmet need keluarga berencana yang tingg dapat menyebabkan terjadinya unsafe abortion, hal ini disebabkan karena adanya kehamilan yang tidak diinginkan sehingga risiko dan komplikasi kematian ibu dan bayi terkait dengan aborsi yang tidak aman akan meningkat. ${ }^{17}$

AKI kota Padang pada tahun 2017 tercatat sebesar 16 per 100.000 kelahiran hidup, AKB berjumlah 89 per 1000 kelahiran hidup dan Angka Kematian neonatal sebesar 52 per 1000 kelahiran hidup. Wilayah kerja Puskesmas Bungus memiliki jumlah lahir mati sebanyak 4 kasus dari total kelahiran sebanyak 480 dan Angka kematian ibu sebanyak 1 kasus. ${ }^{18}$

Survei pendahuluan yang dilakukan dalam wilayah kerja Puskesmas Bungus dari 2 orang bidan dan 10 orang wanita usia subur yang ada saat itu didapatkan informasi bahwa tingginya angka unmet need KB disebabkan bahwa jangkauan fasilitas kesehatan yang sangat jauh karena kondisi daerah yang luas, fasilitas pelayanan yang masih kurang, serta kurangnya sosialisasi KB yang dilakukan oleh bidan setempat. Sosialisasi KB diberikan dengan pamflet yang tersedia di puskesmas, sedangkan tidak semua wanita usia subur yang dapat membaca pamflet tersebut dikarenakan tidak mengunjungi puskesmas untuk melakukan pelayanan kesehatan maupun konsultasi keluarga berencana. Selain itu sosialisasi diberikan dengan penyuluhan yang dilakukan di puskesmas oleh bidan secara berkelompok pada beberapa kali, namun masih kurang efektif karena kehadiran wanita usia subur yang masih sedikit.

Berdasarkan latar belakang di atas, maka penulis tertarik untuk melakukan penelitian tentang analisis karakteristik wanita usia subur, dukungan suami, dan peran bidan terhadap unmet need keluarga berencana (KB) di wilayah kerja Puskesmas Bungus Kota Padang Tahun 2019.

\section{METODE}

Penelitian ini menggunakan rancangan analitik dengan desain penelitian case control. Penelitian ini dilakukan di Wilayah Kerja Puskesmas Bungus Kota Padang.

Penelitian dilakukan dengan metode wawancara langsung dengan lembar kuesioner 
sebagai acuan pada bulan April sampai Juni 2019. Populasi penelitian ini adalah seluruh wanita usia subur yang berada pada usia 15-49 tahun yang termasuk unmet need KB (wanita usia subur yang membutuhkan KB tetapi tidak terpenuhi) dan met need KB (wanita usia subur yang menggunakan kontrasepsi) yang berada di wilayah kerja Puskesmas Bungus. Subjek penelitian yang dipilih adalah memenuhi kriteria inklusi dan tidak termasuk kriteria ekslusi, dengan teknik pengambilan sampel secara sistematic random sampling.

Variabel yang diteliti dalam penelitian dibagi dalam dua kelompok yaitu unmet need $\mathrm{KB}$ dan karakteristik wanita usia subur (umur, pendidikan terakhir, jumlah anak, status ekonomi), dukungan suami dan peran bidan.

Analisis bivariat menggunakan perbandingan proporsi antara variabel dependen (kategorik) dengan variabel independen (kategorik) dengan uji statistik Chi-Square untuk mengetahui hubungan antara variabel dependen dan variabel independen. Hasil analisis dianggap bermakna bila didapatkan $p<0,05$. Analisis multivariat dilakukan dengan tujuan untuk melihat variabel bebas yang paling dominan hubungannya dengan variabel terikat dengan menggunakan regresi logistik ganda dengan melihat $p<0,25$.

HASIL

Tabel 1. Karakteristik responden

\begin{tabular}{|c|c|c|c|c|}
\hline \multirow{3}{*}{ Variabel Penelitian } & \multicolumn{4}{|c|}{$\begin{array}{c}\text { Kebutuhan Keluarga } \\
\text { Berencana }\end{array}$} \\
\hline & \multicolumn{2}{|c|}{ Unmet Need } & \multicolumn{2}{|c|}{ Met Need } \\
\hline & $\mathbf{f}$ & $\%$ & $\mathbf{f}$ & $\%$ \\
\hline \multicolumn{5}{|l|}{ Umur } \\
\hline Berisiko & 88 & 49,4 & 79 & 44.4 \\
\hline Tidak Berisiko & 90 & 50,6 & 99 & 55,6 \\
\hline \multicolumn{5}{|l|}{ Pendidikan Terakhir } \\
\hline Pendidikan Dasar & 31 & 17,4 & 39 & 21,9 \\
\hline Pendidikan Menengah & 147 & 82,6 & 138 & 77,5 \\
\hline Pendidikan Tinggi & 0 & 0 & 1 & 0,6 \\
\hline \multicolumn{5}{|l|}{ Jumlah Anak } \\
\hline$\geq 5$ orang & 1 & 0,6 & 1 & 0,6 \\
\hline 2-4 orang & 146 & 82 & 163 & 91,6 \\
\hline 1 orang & 31 & 17,4 & 14 & 7,9 \\
\hline \multicolumn{5}{|l|}{ Status Ekonomi } \\
\hline Miskin & 59 & 33,1 & 54 & 30,3 \\
\hline Tidak Miskin & 119 & 66,9 & 124 & 69,7 \\
\hline
\end{tabular}

Tabel 1 menunjukkan bahwa karakteristik responden dengan unmet need $\mathrm{KB}$ yaitu memiliki umur berisiko 49.4\%, berpendidikan menengah $82,6 \%$, jumlah anak $2-4$ orang $82 \%$, dan status ekonomi tergolong miskin $33,1 \%$.

Tabel 2. Dukungan suami dan peran bidan

\begin{tabular}{lcccc}
\hline \multirow{2}{*}{ Variabel Penelitian } & \multicolumn{3}{c}{ Kebutuhan Keluarga Berencana } \\
\cline { 2 - 5 } & \multicolumn{2}{c}{ Unmet Need } & \multicolumn{2}{c}{ Met Need } \\
\cline { 2 - 5 } & $\mathbf{f}$ & $\%$ & $\mathbf{f}$ & $\%$ \\
\hline Dukungan Suami & & & & \\
Tidak Mendukung & 130 & 73 & 6 & 3,4 \\
$\begin{array}{l}\text { Mendukung } \\
\text { Peran Bidan }\end{array}$ & 48 & 27 & 172 & 96,6 \\
$\quad$ Kurang Baik & 134 & 75,3 & 97 & 54,5 \\
Baik & 44 & 24,7 & 81 & 45,5 \\
\hline
\end{tabular}

Berdasarkan Tabel 2 dapat dilihat bahwa responden dengan unmet need KB tidak mendapatkan dukungan suami sebanyak 130 responden (73\%), dan menyatakan peran bidan kurang baik sebesar 134 responden $(75,3 \%)$.

\section{ANALISIS BIVARIAT}

Pada analisis ini uji statistik menggunakan chi square sehingga dapat dilihat perbedaan proporsi hubungan dari setiap variabel dengan kemaknaan hubungan pada derajat $\alpha=5 \%$. Analisis bivariat dilakukan dengan uji statistik secara komputerisasi seperti Tabel 3.

Berdasarkan Tabel 3 dapat dilihat bahwa terdapat hubungan antara jumlah anak dengan unmet need $\mathrm{KB}$ dengan nilai $\mathrm{p}=0,026$ dan nilai $\mathrm{OR}=0,428$. Terdapat hubungan antara dukungan suami dengan unmet need keluarga berencana dengan nilai $\mathrm{p}=$ 0,000 dan nilai $\mathrm{OR}=77,639$. Terdapat hubungan antara peran bidan dengan unmet need KB dengan nilai $p=0,000$, dan $O R=2,543$. 
Tabel 3. Hubungan variabel independen (karakteristik wanita usia subur, dukungan suami, dan peran bidan) dan variabel dependen (kebutuhan keluarga berencana) di wilayah kerja Puskesmas Bungus kota Padang tahun 2019

\begin{tabular}{|c|c|c|c|c|c|c|}
\hline \multirow{5}{*}{$\begin{array}{c}\text { Variabel } \\
\text { Independen }\end{array}$} & \multicolumn{4}{|c|}{ Kebutuhan Keluarga } & \multirow{5}{*}{$\mathbf{p}$} & \multirow{5}{*}{$\begin{array}{c}\text { OR } \\
(95 \% \\
\text { Cl) }\end{array}$} \\
\hline & \multicolumn{4}{|c|}{ Berencana } & & \\
\hline & \multirow{2}{*}{\multicolumn{2}{|c|}{$\begin{array}{c}\text { Unmet } \\
\text { Need }\end{array}$}} & \multirow{2}{*}{\multicolumn{2}{|c|}{ Met Need }} & & \\
\hline & & & & & & \\
\hline & $f$ & $\%$ & $f$ & $\%$ & & \\
\hline Umur & & & & & & 1,225 \\
\hline Berisiko & 88 & 49,4 & 79 & 44.4 & 0,396 & $\begin{array}{r}(0,808- \\
1,859)\end{array}$ \\
\hline Tidak Berisiko & 90 & 50,6 & 99 & 55,6 & & \\
\hline Pendidikan & & & & & & 0,784 \\
\hline Terakhir & & & & & & \\
\hline $\begin{array}{l}\text { Pendidikan } \\
\text { Dasar }\end{array}$ & 31 & 17,4 & 39 & 21,9 & 0,334 & $\begin{array}{r}(0,467- \\
1,316)\end{array}$ \\
\hline Pendidikan & 147 & 82,6 & 138 & 77,5 & & \\
\hline Menengah & & & & & & \\
\hline Pendidikan & 0 & 0 & 1 & 0,6 & & \\
\hline Tinggi & & & & & & \\
\hline Jumlah Anak & & & & & & 0,428 \\
\hline$\geq 5$ orang & 1 & 0,6 & 1 & 0,6 & 0,026 & $\begin{array}{l}(0,224- \\
0,817)\end{array}$ \\
\hline 2-4 orang & 146 & 82 & 163 & 91,6 & & \\
\hline 1 orang & 31 & 17,4 & 14 & 7,9 & & \\
\hline Status & & & & & & 1,138 \\
\hline Ekonomi & & & & & & \\
\hline Miskin & 59 & 33,1 & 54 & 30,3 & 0,649 & $\begin{array}{r}(0,728- \\
1,780)\end{array}$ \\
\hline Tidak Miskin & 119 & 66,9 & 124 & 69,7 & & \\
\hline Dukungan & & & & & & 77,639 \\
\hline Suami & & & & & & \\
\hline Tidak & 130 & 73 & 6 & 3,4 & 0,001 & $(32,244$ \\
\hline Mendukung & & & & & & 186,941 \\
\hline Mendukung & 48 & 27 & 172 & 96,6 & & \\
\hline Peran Bidan & & & & & & 2,543 \\
\hline Kurang Baik & 134 & 75,3 & 97 & 54,5 & 0,001 & $\begin{array}{l}(1,621- \\
3,991)\end{array}$ \\
\hline Baik & 44 & 24,7 & 81 & 45,5 & & \\
\hline
\end{tabular}

\section{ANALISIS MULTIVARIAT}

Tabel 4. Model akhir analisis multivariat

\begin{tabular}{lccccc}
\hline Variabel & B & Wald & Sig & OR & Cl 95\% \\
\hline Jumlah & $-1,803$ & 18,785 & 0,001 & 0,165 & $0,073-$ \\
Anak & & & & & 0,373 \\
Dukungan & 4,610 & 96,446 & 0,001 & 100,504 & $40,050-$ \\
Suami & & & & & 252,214 \\
Peran Bidan & 0,904 & 0,390 & 0,010 & 2,468 & $1,246-$ \\
& & & & & 4,888 \\
\hline
\end{tabular}

Hasil analisis secara multivariat dapat disimpulkan bahwa dari keseluruhan variabel independen yang diduga berhubungan dengan unmet need KB terdapat satu variabel yaitu dukungan suami yang paling berhubungan terhadap unmet need KB dengan $p$ value $0,001<0,05$. Nilai OR diperoleh 100,504 yang berarti dukungan suami dengan kategori tidak mendukung mempunyai peluang 100,504 kali untuk terjadinya unmet need KB.

\section{PEMBAHASAN}

Pada penelitian ini didapatkan hasil yaitu terdapat hubungan yang signifikan pada jumlah anak, dukungan suami, dan peran bidan dengan $p<0,05$, sedangkan pada umur, pendidikan terakhir, status ekonomi, tidak terdapat hubungan yang signifikan dengan $p>0,05$.

Hasil analisis multivariat dengan regresi logistik ganda menggunakan metode enter diperoleh 1 variabel yang paling dominan terhadap unmet need $\mathrm{KB}$ yaitu dukungan suami.

\section{Hubungan Jumlah Anak dengan Unmet Need Keluarga Berencana (KB)}

Hasil penelitian menunjukkan bahwa wanita usia subur dengan unmet need KB dengan jumlah anak sebagian besar berjumlah 2-4 orang. Hasil uji statistik mendapatkan nilai $p=0,026(p<0,05)$, yang berarti terdapat hubungan yang signifikan antara jumlah anak dengan unmet need KB.

Berdasarkan hasil penelitian dari Siswanto et al tahun 2017 menjelaskan bahwa wanita dengan 2-3 anak, 1,3-1,4 kali lebih mungkin menggunakan kontrasepsi dibandingkan wanita dengan satu anak. Dengan kata lain wanita primipara lebih banyak menggunakan unmet need KB dari pada multipara dan grande multipara. ${ }^{19}$

\section{Hubungan Dukungan Suami dengan Unmet Need Keluarga Berencana (KB)}

Hasil penelitian menunjukkan bahwa wanita usia subur dengan unmet need keluarga berencana yang tidak mendapatkan dukungan suami lebih tinggi

dibandingkan yang mendapatkan dukungan suami. Hasil uji statistik mendapatkan nilai $p=0,001(p<0,05)$. 
Salah satu faktor yang mempengaruhi perilaku masyarakat untuk menggunakan kontrasepsi yaitu adanya faktor pendorong. Faktor pendorong yaitu dukungan suami yang berhubungan dengan penggunaan kontrasepsi. Istri yang tidak mendapatkan dukungan dari suaminya cenderung untuk mengalami unmet need. Seorang istri dalam pengambilan keputusan untuk memakai atau tidak memakai alat kontrasepsi membutuhkan persetujuan dari suami karena suami mempengaruhi otonomi pengambilan keputusan perempuan. ${ }^{20}$

\section{Hubungan Peran Bidan dengan Unmet Need Keluarga Berencana (KB)}

Hasil penelitian menunjukkan bahwa wanita usia subur dengan unmet need KB yang menyatakan persepsi peran bidan kurang baik lebih tingg dibandingkan peran bidan dengan kategori baik. Hasil uji statistik didapatkan nilai $p=0,001 \quad(p<0,05)$, yang berarti terdapat hubungan yang bermakna antara peran bidan dengan unmet need KB.

Peran adalah perilaku individu yang diharapkan sesuai dengan posisi yang dimiliki. Peran yaitu suatu pola tingkah laku, kepercayaan, nilai dan sikap yang diharapkan dapat menggambarkan perilaku yang seharusnya diperlihatkan oleh individu pemegang peran tersebut dalam situasi yang umumnya terjadi. ${ }^{21}$ Hasil penelitian Alayande et al (2016) menjelaskan bahwa bidan memegang peranan dalam mendistribusikan kontrasepsi. Peran bidan yang baik telah meningkatkan jumlah individu yang mengakses layanan keluarga berencana, meningkatkan penggunaan akseptor $\mathrm{KB}$, serta mengurangi tingkat rujukan persalinan. Bidan yang dapat menjalankan perannya sebagai pembimbing dalam kesehatan reproduksi wanita akan dapat menjadi penentu dalam peningkatan penggunaan kontrasepsi bagi wanita. ${ }^{22}$

\section{Faktor yang Tidak Berhubungan terhadap Unmet Need Keluarga Berencana}

Analisis yang dilakukan terhadap 356 responden terhadap variabel yang diteliti menunjukkan ada yang menunjukkan memiliki hubungan yang bermakna terhadap unmet need KB namun ada juga yang variabel yang tidak memiliki hubungan terhadap unmet need KB. Variabel yang tidak memiliki hubungan terhadap unmet need KB adalah umur $p=0,396$, pendidikan terakhir $p=0,334$, status ekonomi $p=0,649$.

Unmet need KB biasanya rendah pada wanita usia 15-24 dan puncak bagi banyak wanita di usia tiga puluhan dan kemudian menurun pada empat puluhan. Hal ini dipengaruhi oleh pengalamannya dan kesadaran tentang kontrasepsi di kalangan wanita yang lebih tua yang mengurangi kemungkinan unmet need KB di kalangan mereka. ${ }^{17}$

Kelompok wanita usia subur dengan unmet need KB sebagian besar memiliki pendidikan menengah dengan hasil uji statistik didapatkan nilai $\mathrm{p}=$ $0,334(p>0,05)$. Berbeda dengan negara di Afrika seperti di Ethiopia yang menjelaskan bahwa pendidikan perempuan sebagai salah satu faktor penyebab unmet need KB. Wanita yang memiliki tingkat pendidikan kurang dari menengah mempunyai risiko sekitar empat kali lebih untuk unmet need KB dibandingkan yang memiliki tingkat pendidikan menengah ke atas. Semakin tinggi tingkat pendidikan wanita, akan lebih memilih untuk menggunakan kontrasepsi jangka panjang untuk menjarangkan maupun pembatasan kelahiran dari pada unmet need KB. ${ }^{23}$

Hasil penelitian menunjukkan bahwa wanita usia subur dengan unmet need KB sebagian besar berada pada status ekonomi kategori tidak miskin. Hasil uji statistik mendapatkan nilai $p=0,649$ ( $p>0,05)$.

Status ekonomi berhubungan erat dengan pendapatan. Pendapatan adalah keseluruhan penghasilan yang diperoleh oleh anggota keluarga. Wanita dengan tingkat kesejahteraan keluarga lebih baik memiliki kemampuan lebih untuk mengatasi permasalahan biaya penggunaan pelayanan KB dibandingkan dengan tingkat kesejahteraan lainnya. Terdapat hubungan signifikan antara faktor sosial ekonomi dengan pemenuhan $\mathrm{KB}$, yaitu seorang wanita yang berstatus ekonomi baik akan menggunakan kotrasepsi lebih besar daripada perempuan miskin. ${ }^{24}$

\section{SIMPULAN}

Faktor yang berhubungan dengan unmet need KB di Wilayah Kerja Puskesmas Bungus Kota Padang yaitu jumlah anak, dukungan suami, dan peran bidan 
dengan variabel yang paling dominan adalah dukungan suami.

Faktor yang tidak berhubungan dengan unmet need KB di Wilayah Kerja Puskesmas Bungus Kota Padang yaitu umur, pendidikan terakhir, dan status ekonomi.

\section{SARAN}

Institusi terkait dalam penatalaksanaan keluarga berencana di wilayah kerja Puskesmas Bungus Kota Padang seperti puskesmas dan perwakilan BKKBN, hendaknya melakukan asuhan keluarga berencana dengan menggunakan ABPK-KB serta melakukan penyuluhan yang berkesinambungan kepada Wanita usia subur dan juga melibatkan pasangannya (suami)

\section{UCAPAN TERIMA KASIH}

Terima kasih dan penghargaan peneliti sampaikan kepada Kepala Puskesmas, Bidan Koordinator KIA-KB, PLKB perwakilan BKKBN Kota Padang yang telah memberikan izin dan bantuan dalam penyelesaian penelitian ini.

\section{DAFTAR PUSTAKA}

1. Surapaty S. Kebijakan program kependudukan, keluarga berencana, dan pembangunan keluarga dalam mendukung keluarga sehat (rapat kerja kesehatan nasional gelombang II). Jakarta: BKKBN; 2016.

2. Handayani S. Buku ajar pelayanan keluarga berencana. Yogyakarta: Pustaka Rihama; 2010.hlm.20-3.

3. BKKBN. Pemantauan pasangan usia subur melalui mini survei Indonesia. Jakarta: BKKBN; 2013.

4. Badan Pusat Statistik. Survei Demografi dan Kesehatan Indonesia (SDKI) 2017. Jakarta; 2017.

5. BKKBN. Profil Kependudukan dan Pembangunan di Indonesia. Jakarta: BKKBN; 2015.

6. Kementerian Kesehatan RI (Kemenkes RI). Profil kesehatan Indonesia. Jakarta:Kemenkes RI; 2016.

7. Kemenkes RI. Kesehatan dalam kerangka sustainable development goals (SDG'S). Jakarta: Kemenkes RI; 2015.
8. Nzokirishaka, Athanase, Itua I. Determinants of unmet need for family planning among married women of reproductive age in Burundi: a CrossSectional Study. Contracept Reprod Med. 2018;3(11):1-13.

9. Lutalo T, Ron G, John S. Unfulfilled need for contraception among women with unmet need but with the intention to use contraception in Rakai, Uganda: a Longitudinal Study. BMC Women's Health. 2018;18(60):1-7.

10. Genet E, Gedefaw A, Ejigu T. Determinants of unmet need for family planning among currently married women in Dangila town administration, Awi Zone, Amhara regional state; a cross sectional study. Reprod Health. 2015;12(42):1-5.

11. Ernani. Konseling sebagai upaya mengurangi unmet need KB. J Husada Mahakam. 2012;3(4):144-53.

12. Umariyah NS, Wahyati E, Hardjono H. Peran bidan dalam pelaksanaan program keluarga berencana berdasarkan Permenkes 1464/Menkes/Per/X/2010 tentang izin dan penyelenggaraan praktik bidan. Soepra J Huk Kesehat. 2015;1(1):91-105.

13. BKKBN. Survei Demografi dan Kesehatan Indonesia. Jakarta: BKKBN; 2012.

14. BKKBN. Review program kependudukan keluarga berencana dan pembangunan keluarga (KKBPK) tahun 2017 provinsi Sumatera Barat. Jakarta: BKKBN; 2017.

15. BKKBN Kota Padang. Laporan Tahunan BKKBN Kota Padang. Padang: BKKBN Kota Padang;2017.

16. Dinas Kesehatan Kota Padang. Laporan pemantauan wilayah setempat keluarga berencana (KB) Dinas Kesehatan Kota Padang. 2018.

17. Lakew D, Tesyafe D, Mekonnen H, Admasu M. A Binary logistic regression model with complex sampling design of unmet need for family planning among all women aged (15-49) In Ethiopia. Afr Health Sci. 2017;17(3):637-46.

18. Dinas Kesehatan Kota Padang. Laporan pemantauan wilayah setempat bagian kesehatan ibu dan anak- keluarga berencana (KIA-KB) Dinas Kesehatan Kota Padang. 2017. 
19. Siswanto AW, Setyawan A, Wahyu A, Prihyugiarto $T$, Julian F. Levels, trends and correlates of unmet need for family planning among post partum women in Indonesia: 2007-2015. BMC Womens Health. 2017;17-120.

20. Machiyama K, Casterline M, Akhter F, Obares F. Reasons for unmet need for family planning, with attention to the measurement of fertility preferences; protocol for a multi-site cohort study. Reprod Health. 2017;14-23.

21. Sarwono. Ilmu kebidanan. Jakarta: Yayasan Bina Pustaka Sarwono Prawirohardjo; 2010.
22. Alayande A, Mamman F, Adedeji O, Zakari A. Midwives as drivers of reproductive health commodity security in Kaduna State, Nigeria. Eur J Contracept Reprod Heal Care. 2016;21(3):207-12.

23. Mota K, Reddy S, Getachew B. Unmet need of long-acting and permanent family planning methods among women in the reproductive age group in Shashemene town, Oromia Region, Ethiopia. BMC Womens Health. 2015;15-51.

24. Katulistiwa R. Determinant unmet need KB pada wanita menikah di kecamatan Klabang Kabupaten Bondowoso. E-Journal Pustaka Kesehat. 2014;2(2):277-84. 